UDC 657.421.3.01

JEL Classification: A10 M40

http://doi.org/10.21272/mmi.2019.1-10

Zenovii-Mykhailo Zadorozhnyi,

D.Sc., Professor, Ternopil National Economic University, Ukraine

Valentyna Yasyshena,

Ph.D., Associate Professor, Ternopil National Economic University, Ukraine

\title{
INTANGIBLE ASSETS AS AN ACCOUNTING AND MANAGEMENT OBJECT
}

Abstract. The article deals with the views of foreign and domestic economists on understanding the essence of the notion of intangible assets $(\mathrm{IA})$ and its role in the management system of the enterprise. The main purpose of the study is to improve the conceptual apparatus of this category. Systematization of literary sources and approaches to understanding the essence of the IA has shown that there are different approaches to the definition of their essence (economic, legal, accounting, evaluation), which are disclosed in the scientific literature and regulatory documents. The topicality of solving this scientific problem lies in the fact that due to the existence of differences in economic, legal, accounting and valuation approaches to understanding the essence of IA there is a significant gap between the methodology of accounting IA and modern management requirements. The difficulty in interpreting the concept of IA is caused by the fact that they include different objects by nature. The signs characterizing IA are analyzed and singled out. The advantages and disadvantages of topical approaches to the definition of the nature of the IA, which are disclosed in the scientific literature and normative legal documents, are revealed. It is proposed to clarify the interpretation of the concept of «intangible assets» where the economic, legal, accounting, valuation aspects are combined. It is recommended to consider intangible assets as identifiable and evaluated long-term and current assets that are not physically embodied, and represent the rights to intellectual property, the use of natural resources, property and organizational and economic privileges. In addition, they are able to bring economic benefits and have the property to influence the formation of value enterprises, increase their profitability and competitiveness. It is proposed to clarify the wording of the definition of IA in the Law of Ukraine "On state regulation of activities in the field of technology transfer», which will more fully disclose the rights to IA objects for the groups listed in PAS 8, the Accounts plan and in the Methodological Recommendations for accounting of intangible assets.

Keywords: recognition, identification, intellectual property, intellectual capital, fixed assets, intangible assets (IA), non-monetary assets, non-current assets, accounting, valuation.

Introduction. The notion of intangible assets $(I A)$ is used in the accounting and valuation activities, legal and managerial spheres, therefore this economic category has a number of differences in its interpretation: in the provisions of the accounting standards of (PAS), in regulatory documents and in the economic literature. The complexity of accounting intangible assets is that by nature they include different objects. Due to the fact that today there are and continue to be created various intangible assets, as well as due to differences in economic, legal, accounting and valuation approaches to understanding their essence, there is a significant gap between the methodology of accounting IA and modern requirements of the economy. This necessitates the study of the essence and refinement of the concept of IA to create a unified methodological approach.

Literature Review. Theoretical and methodological issues concerning the disclosure of the essence of intangible assets and their role in the activities of economic entities and the economy as a whole are considered in a number of scientific works of such scholars as T. M. Banasko (2010), I. A. Bihdan (2003), I. A. Blank (2007), N. M. Brazilii (2007), A. Delios, P. W. Beamish (2001), J. H. Dunning (1993), V. M. Dyba (2017), E. S. Hendriksen, M. F. Van Breda (2000), J. R. Hitzner (2008), Yu. A. Horohovets (2018), L. A. Joia (2000), R. S. Kaplan, D. P. Norton (2004), I.I. Kryshtopa (2008), B. Lev (2003), I. M. Lepethan (2010), R. Morck, B. Yeung (1992), B. Needles, H. Anderson, J. Coldwell (2004), I. Nonaka, H. Takeuchi (1995), V.F. Palii, V.M. Palii (1998), Yu.V Pysarenko (2008), M.V. Plekan (2013), T.V. Poliova (2006),

Cite as: Zadorozhnyi, Z.-M., \& Yasyshena, V. (2019). Intangible Assets as an Accounting and Management Object. Marketing and Management of Innovations, 1, 132-142. http://doi.org/10.21272/mmi.2019.1-10 
V.V. Satovskyi (1998), V.V. Sopko (2000), I. Ye. Starko (2015), T.A. Stewart (1997), Sun Lin (2001), V.S. Shelest (2014), S.V. Shulha (2006), O. M. Udovychenko (2007), O.V. Vakun (2013), and others.

However, despite the considerable progress and high scientific level of publications on these issues, many aspects regarding the importance of the role of intangible assets in the modern economy require further study. The dynamics of the post-industrial society, which is associated with the rapid development of the services sector, education and science, a significant increase in specialized knowledge in various fields, creates new challenges aimed at forming a unified theoretical framework that reflects all aspects of such a difficult economic category as IA. Today, the regulatory framework for recording and conducting transactions with IA is in a state of change and needs further improvement. In view of the above, it is necessary to analyze existing approaches to understanding the nature of the IA and to improve their interpretation.

The purpose is to study domestic and foreign experience to understand the essence of the concept of «intangible asset» and the improvement of the conceptual apparatus of this category.

Results. Currently, economists have highlighted key positions taken by the IA in the development of the world economy. The evidence of this is the work carried out by Ocean Tomo (Ocean Tomo, 2017), which provides intellectual property asset management services, and conducts annual research on the market value of (IA). They found that 500 US joint-stock companies with the largest market capitalization for 40 years had a change in a specific weight of tangible assets in relation to intangible assets. During this period, the share of (IA) increased from $17 \%$ to $84 \%$ (Fig. 1). This indicates that there is a steady upward trend in share growth (IA) over a long period in the market value of companies. Therefore, today there is a need to improve the organization of categorical apparatus, accounting methodology (IA) in order to improve their management.

\section{COMPONENTS of S \& P 500 MARKET VALUE}

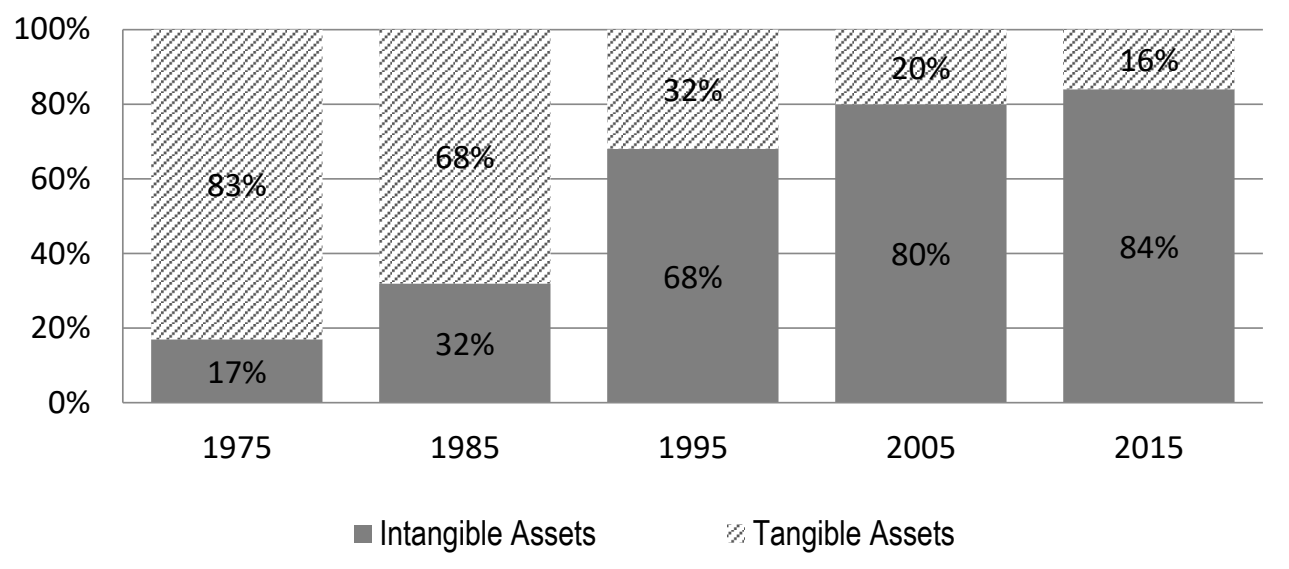

Figure 1. Intangible Asset Market Value Study

Sources: Intangible Asset Market Value Study, 2017 (Ocean Tomo, 2017).

Among economists, there are different approaches to defining the notion of «intangible assets» such as economic, legal, accounting, evaluation. These approaches reveal the essence, place, role and value of intangible assets for the development and implementation of financial and economic activities of the entity. At the same time, a variety of approaches to the identification of intangible assets creates complexity and difficulty understanding their essence, disclosed in the scientific literature and regulatory documents on this issue. The explanatory economic dictionary (2009) states that intangible values are values that are not 
physical objects but have a monetary value. These are patents, technological and technical latest developments, projects, other intellectual property objects, leases and other rights.

According to E.S. Hendrixen and M.F. Van Bredf (2000), intangible assets are objects that do not have a real embodiment. In order for an asset to be considered an intangible asset, it is necessary that it corresponds to the definition of an asset, it is measurable, significant and reliable. B. Lev (2003), treats intangible assets as intangible sources of value that are generated by innovations, unique organizational projects or practices of human resources management.

J. R. Hitchner (2008) believes that intangible assets are codified descriptions of specific knowledge that can be owned and, if necessary, traded. According to B. Needles, H. Andersen and D. Caldwell (2004), intangible assets (non-material assets) are long-term assets that are not physically present. Their value is the long-term rights or benefits that they give to the owner (patents, copyrights, firm prices, trademarks, special privileges, licenses, formulas, technology).

According to R. S. Kaplan and D. R. Norton (2004), intangible assets are the main source of sustainable value creation. They see them as «knowledge that exists in the organization to create a different advantage» and "the ability of employees to meet the needs of customers». According to scientists, intangible assets include such diverse subjects as patents, copyrights, labour force knowledge, management, information systems and work processes. Delios A. and Beamish P. W. (2001) outlined the prospects of IA's influence on international expansion and its success. They noted that various companies that carry out geographic business diversification must adopt the existing benefits of intangible assets in order to be competitive in the new market conditions. Their works also mentioned the views of other scholars who emphasized the important role of IA in business development, namely: Intangible assets are the basis for company motivation to enter new geographic markets (Dunning, 1993). Intangible assets create advantages in their country, which can be used in foreign markets. Intangible assets encourage firms to geographically diversify, as growth in new markets does not reduce the value of assets with intensive use of information on the domestic market (Morck \& Yeung, 1998).

L.A. Joia (2000) notes that the IA is the core of the knowledge economy. The current balance sheet and profit and loss account are reports on the company's operations for today but are not reliable tools for evaluating its results in the near future. According to Stewart (1997), accountants cannot measure the company's intellectual capital. And this hidden treasure today is something that really matters in society. Knowledge replaced the land, labour and capital as a contribution of knowledge-intensive companies. Despite the progress made in understanding the nature of knowledge - both tacit and explicit - and its transfer mechanisms within the company (Nonaka and Takeuchi, 1995) and among their partners (Badaracco, 1991), the long and difficult road of negotiations ahead of us before we will have reliable measurements for this intangible capital. According to V.F. Palii and V.M. Palii (1998) the package of intangible assets is property objects that do not have the material content or this content is not decisive for its productive use, or material and substance content is not considered due to legal constraints. Sopko V. (2000) under the intangible assets understands the par value of objects of industrial and intellectual property, as well as other similar property rights, which are determined by the object of ownership of a particular enterprise (economy).

Blank I. A. (2007) notes that intangible assets are a group of assets of an enterprise that does not have a real form, including objects of intellectual (including industrial) ownership. To this group of assets of an enterprise, he refers goodwill, acquired by the enterprise the right to use certain natural resources, software products, trademarks, patents, know-how and other similar types of property values, which are established by the relevant legislation and are reflected in the balance sheet of the enterprise. Udovychenko O. M. (2007) offered his approach to understanding all non-material objects (NMO), dividing them into three groups, which include: intangible assets (IA); intangible resources (IR); non-material factors (NMF). He justifies his approach by the fact that it is impossible to combine all objects that are related to non-material in one 
definition. Intangible assets $(I A)$. An entity is identified as an intangible asset if it has no material structure, is owned by the organization, may be separated from the organization for further sale or other disposal and is a source of future economic benefits. Intangible resources (IR). Objects that do not have a material structure controlled by the company, which is the result of operations carried out by the organization earlier or incurred costs and are able to bring organizations the economic benefits in the future. Non-material factors (NMF). The unformalized and uncontrolled possibilities of the enterprise to create new values that provide it with a competitive advantage.

Also, for the disclosure of the nature of the NMA, the results of the dissertation research of domestic scientists on the accounting, analysis and audit of intangible assets from 1998 to 2018 on the speciality 08.00.09 (08.06.04) were studied. Approaches to the definition of the essence of the IA are set out in the dissertation research of domestic scientists (1998-2018) are given in Table. 1.

Table 1. Approaches to the definition of the essence of the IA presented in the dissertation research of domestic scientists (1998-2018)

\begin{tabular}{|c|c|}
\hline $\begin{array}{l}\text { Author, year of the } \\
\text { dissertation defence }\end{array}$ & The essence of intangible assets \\
\hline 1 & 2 \\
\hline $\begin{array}{l}\text { V.V. Satovskyi } \\
\text { (1998) }\end{array}$ & $\begin{array}{l}\text { Irreversible long-term assets that are not material, but have value and can bring profits } \\
\text { to the enterprise }\end{array}$ \\
\hline Lin Sun (2001) & $\begin{array}{l}\text { Irreversible long-term assets that do not have a material form, but have cost and } \\
\text { functionally can bring profits to the enterprise }\end{array}$ \\
\hline $\begin{array}{l}\text { I. A. Bihdan } \\
\text { (2003) }\end{array}$ & $\begin{array}{l}\text { They are one of the types of enterprise resources, representing certain rights and } \\
\text { benefits that allow the owner to engage in business activities for the purpose of obtaining } \\
\text { economic benefits }\end{array}$ \\
\hline $\begin{array}{l}\text { T. V. Pliova } \\
(2006)\end{array}$ & $\begin{array}{l}\text { Legally recognized non-negotiable assets of the enterprise, in the form of various rights } \\
\text { that have a special purpose, real value and are capable of bringing their owner (user) } \\
\text { profit or other benefits }\end{array}$ \\
\hline $\begin{array}{l}\text { S. V. Shulha } \\
\text { (2006) }\end{array}$ & $\begin{array}{l}\text { Economic and legal interpretation of intangible assets is given. By legal criteria, the rights } \\
\text { arising from licensing, copyright and other transactions, and not licenses themselves, } \\
\text { software products, trademarks, etc., are recognized under intangible assets. Rights and } \\
\text { other intangible assets may also arise from an enterprise resulting from the conclusion } \\
\text { of civil-law agreements, which include, in particular, copyright agreements, research and } \\
\text { development agreements. It is proved that the economic criteria of assigning objects to } \\
\text { intangible assets are the possibility of their identification, the ability to profit and long- } \\
\text { term (more than a year) the nature of the use of intangible assets at the enterprise }\end{array}$ \\
\hline $\begin{array}{l}\text { N.M. Brazilii } \\
(2007)\end{array}$ & $\begin{array}{l}\text { The essence of intangible assets manifests itself in the fact that they are one of the types } \\
\text { of enterprise resources that represent various rights and privileges, including intellectual } \\
\text { property obtained through intellectual activity, which enables the holder to carry on } \\
\text { business activities in order to obtain additional economic benefits compared to } \\
\text { competitors. Having non-material nature, they become noticeable only in the process of } \\
\text { production and sale of products, and only in combination with means, objects of labour } \\
\text { and labour force, because their effect is manifested only in such a combination. }\end{array}$ \\
\hline $\begin{array}{l}\text { I. I. Kryshtopa } \\
(2008)\end{array}$ & $\begin{array}{l}\text { Identify an intangible asset as a non-monetary asset that is not material in nature as a } \\
\text { resource of an enterprise controlled by it as a result of past events and has a material } \\
\text { medium that is substantiated by proprietary rights, the use of which will result in obtaining } \\
\text { expected economic benefits in the future, can be identified, reliably evaluated and used } \\
\text { for more than } 12 \text { months in various business activities of the entity }\end{array}$ \\
\hline
\end{tabular}




\section{Continue Table 1}

\begin{tabular}{|c|c|}
\hline 1 & 2 \\
\hline $\begin{array}{l}\text { Yu. V. Pysarenko } \\
(2009)\end{array}$ & $\begin{array}{l}\text { Intangible assets are non-monetary assets that are non-material, can be identified and held } \\
\text { by the enterprise for future economic benefits. The author specified methodical approaches } \\
\text { to the essence of intangible assets through a more complete definition of the features and } \\
\text { characteristics of this type of assets }\end{array}$ \\
\hline $\begin{array}{l}\text { T. M. Banasko } \\
(2010)\end{array}$ & $\begin{array}{l}\text { Intangible assets in the broad sense should be understood as the totality of intangible } \\
\text { non-monetary factors having the nature of exclusive rights and ensuring the receipt of } \\
\text { economic benefits in the future. }\end{array}$ \\
\hline $\begin{array}{l}\text { I. M. Lepetan } \\
(2010)\end{array}$ & $\begin{array}{l}\text { These are valuable non-monetary assets, property rights, which are part of the } \\
\text { intellectual capital of an enterprise, which is created independently or is engaged from } \\
\text { the party and capable of bringing economic benefits. }\end{array}$ \\
\hline $\begin{array}{l}\text { O. V. Vakun } \\
\text { (2013) }\end{array}$ & $\begin{array}{l}\text { In the broad sense, as a collection of all intangible assets (including intellectual capital } \\
\text { and intangible assets obtained not as a result of intellectual activity), which meet the } \\
\text { requirements for their recognition as assets in accordance with the national P (S) BO }\end{array}$ \\
\hline $\begin{array}{l}\text { M. V. Plekan } \\
(2013)\end{array}$ & $\begin{array}{l}\text { The author summarizes three main approaches to the definition of the concept of } \\
\text { intangible assets: economic, legal and accounting (economic resource and capital, object } \\
\text { of law, assets) }\end{array}$ \\
\hline $\begin{array}{l}\text { V. S. Shelest } \\
(2014)\end{array}$ & $\begin{array}{l}\text { The set of documented, exclusive and non-exclusive proprietary rights to intellectual } \\
\text { property rights, rights to use property rights and specific rights that allow identifying non- } \\
\text { monetary assets and capable of bringing future economic benefits }\end{array}$ \\
\hline $\begin{array}{l}\text { I. Ye. Starko } \\
\text { (2015) }\end{array}$ & $\begin{array}{l}\text { A special type of asset that is not materially identifiable, can be identified and evaluated, } \\
\text { is innovative, generates economic benefits for the enterprise, affects its financial and } \\
\text { economic potential and market value, and has a long useful life }\end{array}$ \\
\hline $\begin{array}{l}\text { V. M. Dyba } \\
(2017)\end{array}$ & $\begin{array}{l}\text { These are resources of non-material origin, providing the economic entity with the ability } \\
\text { to improve the quality of their products (services), systems of their reproduction and } \\
\text { marketing, which increases the competitive advantages of the entity in the market }\end{array}$ \\
\hline $\begin{array}{l}\text { Yu. A. Horokhovets } \\
\text { (2018) }\end{array}$ & $\begin{array}{l}\text { These are inconceivable resources derived from creative or innovative activities, for } \\
\text { which lack physical wear and tear and a high risk of moral wear, a low level of liquidity, } \\
\text { and their total value at the enterprise should be calculated based on the use of non-ad } \\
\text { hoc approaches }\end{array}$ \\
\hline
\end{tabular}

Source: compiled by the authors.

From the above definitions, it is clear that there is no unambiguous approach to the interpretation of the concept of «intangible assets» among scientists. Each author emphasizes his or her the most important signs of IA in his opinion, which best characterize this difficult economic category.

While studying the different approaches of scientists to the interpretation of the concept «intangible assets», it is established that they primarily emphasize the following: it is irreversible long-term assets; have no material form (real embodiment); capable of generating profit (economic benefits); represent the rights and benefits for entrepreneurial activity; a certain type of enterprise resources; they have value (to be appreciated); can be identified (even separately from the enterprise). To a lesser extent, the researchers state that IAs are non-monetary assets, fixed assets (factors, resources), intellectual property objects, property rights, part of the intellectual capital of an enterprise that they are innovative in nature, and they can be owned and trade.

The abovementioned definitions rarely mention such characteristics of IA as controlling by the enterprise; belonging to the organization; having a material carrier; no liquidation value; using for different types and spheres of the enterprise's activity; meet the requirements for recognizing assets in accordance with PAS; having a low level of liquidity; reflection in the balance sheet of the enterprise; lacking of physical wear and risk of moral wear. 
The dubious characteristics of IA that occur in the definition of scholars include the following: created independently or engaged from the party; obtained as a result of creative or innovative activity; are meaningful and reliable; generated by unique organizational projects or practices of human resources management; codified descriptions of specific knowledge; have a par value of objects of industrial and intellectual property and other similar property rights.

In our opinion, the inclusion in the definition of IA attributes «created independently» [19] is not appropriate to introduce into the understanding of the nature of the IA because the issue of internal generation of the IA is quite controversial. In Item 49 IAS 38 «Intangible assets» it is noted that as a result of the incurred expenses for the generation of future economic benefits, the IA is not created, but contributes to the internally generated goodwill that does not meet the criteria for recognition of IA. Also, in paragraph 51-56 IAS 38 it is noted that in order to assess whether the internally generated IA criteria for recognition are to be assessed, it should be classified to a stage of the research or development stage. At the research stage, no IA should be recognized, and at the development stage in accordance with paragraph 57 IAS 38 it is necessary to be cautious to recognize the objects of the IA only if they prove their conformity to the specified conditions in the positions set forth in this paragraph, which in practice make it very difficult. Also, in paragraph 63 it is stated that internally generated brands, titles, titles of publications, lists of clients ... should not be recognized as $I A$.

Inclusion in the definition of such characteristics as «obtained as a result of creative or innovative activity» (Horokhovets, 2018), as well as «generated by unique organizational projects or practice of human resources management» (Lev, 2003) is difficult, for example, to link with the rights to use natural resources (subsoil, other natural resources, geological and other information on the natural environment), property (land, building, rental of premises).

It is noted in E.S. Hendrixen and M.F. Van Breda's (2000) definition that the object to be considered an IA must correspond to the definition of the asset, be measurable, significant and reliable. One can agree that an object will be considered an IA when it meets the definition of an asset and should be measurable, but there are doubts as to the characteristics of the IA object as meaningful and reliable. In our opinion, the main aspect is the recognition of an intangible asset, which includes the following:

- the conformity of an intangible asset to its definition;

- the possibility of identification;

- asset control;

- future economic benefits;

- $\quad$ period of use for more than one year;

- reliable determination of value;

- the presence of supporting documents for the right of use or ownership.

Inclusion to the IA concept such a definition as «codified descriptions of specific knowledge» (Hitchner 2008) is sufficiently complex for perception and understanding of a character that does not reveal the essence of the IA. V. V. Sopko's definition indicates that under the IA it is necessary to understand «the estimated value of objects of industrial and intellectual property and other similar property rights...» (Sopko, 2000). In our opinion, understanding under the IA as «conditional value of objects» is not well-founded, since an important aspect of the recognition of the IA is a reliable determination of its value. Also, in this definition, it is necessary to clarify the disclosure of the IA objects. Under intellectual property, it is necessary to understand the rights enshrined by law in the results of intellectual activity in the artistic, literary, scientific and industrial spheres. Thus, objects of intellectual property rights include rights to commercial designations; rights to industrial property objects; copyright and related rights, which are more detailed in PAS 8. It follows that in the definition it is not necessary to separately distinguish objects of industrial value, because they are part of intellectual property. And other similar property rights should be disclosed if these are rights to use natural resources, property, organizational, economic and other benefits. 
The following approaches of scientists to reveal the essence of the IA, such as obtaining a profit (Pysarenko, 2008), influence on the financial and economic potential and market value of the enterprise (Starko, 2015); the ability to improve the value of products, the system of sales, enhance the competitive advantages (Dyba, 2017) are important. These approaches have a new understanding of the nature of the IAs in the modern economic environment and indicate that IAs have a significant impact on the formation of the value of the enterprise and the competitiveness of the domestic economy as a whole.

It should be noted that the scientific literature also raises questions about the registration of the IAs whose term of use is less than a year (copyrights, rights to know-how, use of property, etc.), the cost of which is written off for expenses of the reporting period, which understated the production potential of enterprises. According to (Bihdan, 2003) it is logical to reflect them in the balance of current assets as high-value intangible assets, as well as to substantiate the need to recognize their assets.

M. Z. Nykoliuk's (2008) work, the IA is identified as negotiable and non-negotiable non-monetary assets that are not material in nature, are objects of intellectual property and other property rights recognized as the object of ownership of a particular physical or legal entity held at the enterprise for future economic benefits. $\mathrm{He}$ also proposes, in connection with the allocation of the category of negotiable intangible assets, the need to formulate appropriate methodological accounting for such objects - separate accounts, valuation and recognition methods, write-offs at expiry, reporting in accounting, etc.

In our opinion, I. A. Bihdan (2003) and M. Z. Nykoliuk's (2008) proposals deserve attention. If, according to economic nature, ineligible non-current tangible assets (INCTA), the whose planned use term exceeds one year, corresponding to low-value high-wearing items ( $\mathrm{HWI}$ ) which are current assets with a planned life of up to one year, then why can they not be reversible (current ones)? I. A. Bihdan (2003) for the accounting of reversible IA proposes to use a sub-account 221 «Quick-wear intangible assets» to the account 22 "Lowvalue and high-value items». Since the IAs do not have the material expression, they cannot be objects that are accounted for in the sub-account 221 «Quick-wear intangible assets». Therefore, in our opinion, these assets would be more appropriate to account for 29 «Current intangible assets» in a separate account.

Today, the issue of accounting for current intangible assets is poorly investigated and controversial. Therefore, further research should be directed to the development of accounting methods for current IA, as well as the introduction of their definition in the accounting theory and practice.

It should be emphasized that trademarks, commercial names, inventions, utility models, industrial designs, plant varieties, animal breeds, layout of integrated circuits, commercial secrets, literary, artistic, musical works, computer programs, phonograms, video games, etc., should not be understood directly under the objects of the IA, but rights to use them.

The accounting and valuation approach to understanding the substance of intangible assets is disclosed in the following legal documents: IAS 38 «Intangible Assets»; International Standard for Valuation 210 «Intangible Assets»; PAS 8 «Intangible assets»; National Public According Standard in the public sector 122 «Intangible assets»; Methodological recommendations on the accounting of intangible assets.

According to the International Standard for Valuation 210 «Intangible Assets», the intangible asset is a non-monetary asset that has economic properties. It has no physical substance but provides rights and economic benefits to its right holder.

In accordance with IAS 38, «Intangible Assets», an intangible asset is a non-monetary asset that has no physical substance and can be identified.

According to PAS 8 «Intangible assets», an intangible asset is a non-monetary asset that is non-material and can be identified.

In the Methodological Recommendations on the Accounting for Intangible Assets, intangible assets are non-monetary assets that are non-material and can be identified (regardless of the useful life (exploitation)). Non-monetary assets are assets, except cash, their equivalents and receivables in the fixed (or definite) amount of money. 
In the IA definition, the ISV 210 notes the economic properties of the IA, but this is a rather blurred characteristic of this economic category, which does not reveal their essence. To eliminate discrepancies in the definition of IA, the guidance given in ISV 210 should be as described in IAS 38.

Currently, the interpretations of the IA concept in the accounting standards and recommendations are identical and do not contradict international standards. However, in the Methodological Recommendations on the Accounting of Intangible Assets, in determining the intangible asset, it is specified that the period of their productive use may be different without any restrictions. This approach can be understood in two ways, and it can make a misunderstanding about the recognition of an intangible asset. Therefore, this clarification should be removed from the definition given in the methodological recommendations.

The legal approach to understanding the essence of the components (various types of intangible assets) included in intangible assets is disclosed and regulated by the following regulatory documents: the Civil Code of Ukraine; Economic Code of Ukraine; Tax Code of Ukraine; Law of Ukraine «On Accounting and Financial Reporting in Ukraine»; Law of Ukraine «On the Protection of Rights to Plant Varieties»; Law of Ukraine «On Protection of Rights to Inventions and Utility Models»; Law of Ukraine «On Protection of Rights to Industrial Designs»; Law of Ukraine «On the Protection of Rights to Trademarks for Goods and Services»; Law of Ukraine «On Copyright and Related Rights»; Law of Ukraine «On Protection of Rights to Integrated Circuits Topography»; Law of Ukraine «On State Regulation of Activities in the Sphere of Technology Transfer».

Of all the above-mentioned laws of Ukraine, the definition of the term «intangible asset» is disclosed only in the Law of Ukraine "On State Regulation of Activities in the Field of Technology Transfer» as an object (s) of intellectual property rights, as well as other similar rights recognized in accordance with the procedure, established by law, object of property rights. The definition of the IA, specified in this law, needs to be clarified and set forth in the following wording: intangible asset is an object (s) of intellectual property rights, as well as rights to use natural resources, property, organizational, economic and other benefits recognized in the procedure established by the legislation. This definition will more fully disclose the rights to the IA objects for the groups listed in PAS 8, the Accounts plan and the Methodological Recommendations for the Accounting of Intangible Assets. Due to the fact that the IA is a complex category, which is constantly improving and changing under the influence of time, it is difficult to disclose in one interpretation all approaches (economic, legal, accounting, valuation). Thus, by combining the economic, legal, accounting, valuation sides to understand the essence of the IA, this notion can be interpreted as the following: intangible assets are identified and evaluated long-term and current assets that are not physically embodied, represent the rights to intellectual property, the use of natural resources, property and organizational and economic privileges, can bring economic benefits and have the ability to influence the formation of the value of the enterprise, increase its profitability and competitiveness.

Conclusions. In the interpretation of the concept of IA scientists emphasize the following main features: non-negotiable long-term assets; have no material form (real embodiment); capable of generating profit (economic benefits); represent the rights and benefits for entrepreneurial activity; one of the types of enterprise resources; have value (to be appreciated); can be identified (including separated from the enterprise). The following should be included to the dubious characteristics of IA, found in the definition of scientists: created independently or involved from the side; obtained as a result of creative or innovative activity; are meaningful and reliable; generated by unique organizational projects or practices of human resources management; codified descriptions of specific knowledge; have the par value of objects of industrial and intellectual property and other similar property rights.

It is recommended to consider intangible assets as identifiable and evaluated long-term and current assets that are not physically embodied, representing the rights to intellectual property, the use of natural resources, property and organizational and economic privileges that are able to bring economic benefits and have the ability to influence formation of the value of the enterprise, increase its profitability and competitiveness. 
Definition of IA, set forth in the Law of Ukraine «On state regulation of activities in the field of technology transfer», is expedient to state in the following: intangible asset is an object (objects) of intellectual property rights, as well as rights to use natural resources, property, organizational, economic and other benefits, recognized in accordance with the procedure established by the law. This definition will more fully disclose the rights to IA objects for the groups set out in PAS 8, the Accounts plan, and the Methodological Recommendations for the Accounting of Intangible Assets. Currently, the question of accounting for negotiable intangible assets is poorly researched and controversial. Therefore, further research should be directed to the development of accounting methods for current IA, as well as the introduction of their definition in the accounting theory and practice.

Author Contributions: conceptualization, Z.-M. Z. and V. Y.; methodology, Z.-M. Z. and V. Y.; formal analysis, Z.-M. Z. and V. Y.; investigation, Z.-M. Z. and V. Y.; resources, Z.-M. Z. and V. Y.; data curation, Z.-M. Z. and V. Y.; writing - original draft preparation, Z.-M. Z. and V. Y.; writing - review and editing, Z.-M. Z. and V. Y.; visualization, Z.-M. Z. and V. Y.; supervision, Z.-M. Z. and V. Y.; project administration, Z.-M. Z. and V. Y.; funding acquisition, Z.-M. Z.

Funding: the research was funded at the expense of the implementation of the state budget theme "Concept of development of management accounting in multinational corporations», the term of execution 2017 - 2019, registration number 0117 U000411.

\section{References}

Badaracco, J. (1991). The Knowledge Link: How Firms Compete through Strategic Alliances, Chapter 5, Harvard Business School Press, Boston, MA, pp. 107-28.

Banasko, T. M. (2010). Bukhhalterskyi oblik i kontrol nematerialnykh aktyviv: otsinka ta poriadok vidobrazhennia [Accounting and control of intangible assets: valuation and display order]. Extended abstract of candidate's thesis. Zhytomyr: Zhytomyr State Technological University [in Ukrainian].

Bihdan, I. A. (2003). Oblik i audyt nematerialnykh aktyviv [Accounting and audit of intangible assets]. Extended abstract of candidate's thesis. Kharkiv: Kharkiv State University of Food Technology and Trade [in Ukrainian]

Blank, I. A. (2007). Upravlenie denezhnymi potokami [Cash flow management] (2nd ed., rev.). Kyiv: Nika-Tsentr [in Russian].

Brazilii, N. M. (2007). Oblik i audyt nematerialnykh aktyviv (na prykladi pidpryiemstv kharchovoi promyslovosti) [Accounting and audit of intangible assets (on example of food-industry enterprises)]. Extended abstract of candidate's thesis. Kyiv: Kyiv Vadym Hetman National Economic University [in Ukrainian].

Delios, A., \& Beamish, P. W. (2001). Survival and profitability: the roles of experience and intangible assets in foreign subsidiary performance. Retrieved from http://citeseerx.ist.psu.edu/viewdoc/download?doi=10.1.1.203.3717\&rep=rep1\&type=pdf .

Dunning, J. H. (1993). Multinational enterprises and the global economy. Don Mills, Ontario: Addison-Wesley Publishing Company.

Dyba, V. M. (2017). Oblik ta analiz nematerialnykh aktyviv v umovakh instytutsiinykh zmin: teoriia i metodolohiia [Accounting and analysis of intangible assets under institutional changes: theory and methodology]. Extended abstract of Doctor's thesis. Kyiv: Kyiv Vadym Hetman National Economic University [in Ukrainian].

Honcharov, S. M. (Ed.), \& Kushnir, S. M. (2009). Tlumachnyi slovnyk ekonomista [A thesaurus for economists]. Kyiv: Tsentr uchbovoi literatury [in Ukrainian].

Horokhovets, Yu. A. (2018). Oblik i analiz nematerialnykh aktyviv v systemi vartisno-oriientovanoho upravlinnia [Accounting and analysis of intangible assets within cost management]. Extended abstract of candidate's thesis. Kyiv: National Academy of Statistics, Accounting, and Audit [in Ukrainian].

Hendriksen, E. S., \& Van Breda, M. F. (2000). Teoriia bukhgalterskogo ucheta [Theory of accounting]. Moscow: Finansy I statistika [in Russian].

Hitchner, J. R. (2008). Otsenka stoimosti nematerialnykh aktivov [Valuation of intangible assets]. Rutgaizer, V. M. (Ed.). Moscow: Maroseika [in Russian].

Intangible Asset Market Value Study. The research is carried out by the company Ocean Tomo, LLC (2017). Retrieved from http://www.oceantomo.com//intangible-asset-market-value-study/

Joia, L. A. (2000). Measuring intangible corporate assets. Linking business strategy with intellectual capital. Retrieved from http://app.ebape.fgv.br/comum/arq/JIC.pdf.

Kaplan, R. S., \& Norton, D. P. (2004). The strategy map: guide to aligning intangible assets. Strategy \& Leadership, 32(5), 10-17. 
Kryshtopa, I. I. (2008). Metodyka ta orhanizatsiia obliku ta kontroliu nematerialnykh aktyviv [Methods and arrangement of accounting and analysis of intangible assets]. Extended abstract of candidate's thesis. Kyiv: Kyiv Vadym Hetman National Economic University [in Ukrainian].

Lepetan, I. M. (2010). Oblik i kontrol nematerialnykh aktyviv u naukovo-doslidnykh hospodarstvakh [Accounting and control of intangible assets in research-and-development centres]. Extended abstract of candidate's thesis. Kyiv: Institute of Agrarian Economics.

Lev, B. (2003). Nematerialnye aktivy: upravlenie, izmerenie, otchetnost [Intangibles: management, measurement, reporting]. (L. I. Lopatnikov, Trans.). Moscow: Kvinto-Konsalting [in Russian].

Mizhnarodnyi standart bukhhalterskoho obliku 38 «Nematerialni aktyvy»: mizhnarodnyi document vid 01.01.2012 [International Accounting Standard 38 Intangible assets: International document from $1^{\text {st }}$ January 2012 ]. Retrieved from http://zakon2.rada.gov.ua/laws/show/929_050/page2 [in Ukrainian].

Mizhnarodnyi standart otsinky 210 «Nematerialni aktyvy» [International Valuation Standard 210 Intangible assets]. Retrieved from http://uto.com.ua/MPO4.pdf [in Ukrainian].

Morck, R., \& Yeung, B. (1992). Internalization: An event study test. Journal of International Economics, 33 (1-2), 41-56.

Needles, B., Anderson, H., \& Coldwell, J. (2004). Printsipy bukhgalterskogo ucheta [Principles of accounting] (2nd ed.). (Ya. V. Sokolova, Ed., Trans.). Moscow: Finansy i statistika [in Russian].

Nonaka, I., \& Takeuchi, H. (1995). The Knowledge-Creating Company: How Japanese Companies Create the Dynamics of Innovation, Oxford University Press, New York, NY.

Nykoliuk, M. Z. (2008). Traktuvannia poniattia «nemateralni aktyvy» v literaturnykh dzherelakh [Definitions of the concept of intangibles in research studies]. Mizhnarodnyi zbirnyk naukovykh prats - International collection of scientific papers, 1(10). Retrieved from http://pbo.ztu.edu.ua/article/view/67076/62477 [in Ukrainian].

Palii, V.F., \& Palii, V. M. (1998). Finansovyi uchet [Financial accounting] (2nd ed.) Moscow: FBK-Press [in Russian].

Plekan, M. V. (2013). Oblik i analiz nematerialnykh aktyviv v umovakh rozvytku informatsiinoi ekonomiky [Accounting and analysis of intangible assets in the information economy]. Extended abstract of candidate's thesis. Lviv: Lviv Commercial Academy [in Ukrainian]

Polozhennia (standart) bukhhalterskoho obliku 8 «Nematerialni aktyvy»: zatverdzheno nakazom MFU vid 18.10.1999r. № 242 [National accounting standard 8 Intangible assets: from 18 th October 1999, No. 242]. Retrieved from http:// http://zakon4.rada.gov.ua/laws/show/z0750-99/ [in Ukrainian].

Poliova, T. V. (2006). Oblik, audyt i analiz nematerialnykh aktyviv [Accounting, audit, and analysis of intangible assets]. Extended abstract of candidate's thesis. Kharkiv: Kharkiv State University of Food Technology and Trade [in Ukrainian].

Pysarenko, Yu. V. (2008). Orhanizatsiia ta metodyka obliku i kontroliu nematerialnykh aktyviv [Organization and methods of accounting and control over intangible assets]. Extended abstract of candidate's thesis. Kyiv: Kyiv Vadym Hetman National Economic University [in Ukrainian]

Satovskyi, V. V. (1998). Oblik i audyt nematerialnykh aktyviv (na materialakh pidpryiemstv ZAT «Ukrtatnafta») [Accounting and audit of intangible assets (on the example of enterprises of the Ukrnafta closed JSC)]. Extended abstract of candidate's thesis. Kyiv: Kyiv National Economic University [in Ukrainian].

Shelest, V. S. (2014). Oblikovo-analitychne zabezpechennia upravlinnia nematerialnymy aktyvamy [Accounting and analytical support for managing intangible assets]. Extended abstract of candidate's thesis. Kyiv: Kyiv Vadym Hetman National Economic University [in Ukrainian].

Shulha, S. V. (2006). Oblik i audyt nematerialnykh aktyviv: teoriia, orhanizatsiia, metodyka [Accounting and audit of intangible assets: theory, organization, and methods]. Extended abstract of candidate's thesis. Kyiv: State Academy of Statistics, Accounting, and Audit [in Ukrainian].

Sopko, V. V. (2000). Bukhhalterskyi oblik [Accounting] (3rd ed., rev.]. Kyiv: Kyiv National Economic University [in Ukrainian].

Starko, I. Ye. (2015). Oblik i kontrol nematerialnykh aktyviv u systemi upravlinnia diialnistiu pidpryiemstva [Accounting and control of intangible assets within enterprise management]. Extended abstract of candidate's thesis. Lviv: Lviv Commercial Academy.

Stewart, T. A. (1997). Intellectual Capital, Doubleday/Currency.

Sun Lin (2001). Oblik, audyt i analiz nematerialnykh aktyviv [Accounting, audit, and analysis of intangible assets]. Extended abstract of candidate's thesis. Kyiv: Kyiv National Economic University [in Ukrainian].

Udovichenko, O. M. (2007). Poniatie, klassifikatsiia, izmerenie i otsenka nematerialnykh aktivov (obiektov) kompanii: podkhody k probleme [The concept, classification, measurement and valuation of intangible assets in a company]. Nauchnye doklady - Scientific reports, 13(R). Retrieved from https://dspace.spbu.ru/bitstream/11701/830/1/13\%28R\%29_2007.pdf [in Russian].

Vakun, O. V. (2013). Oblik i analiz nematerialnykh aktyviv u budivelnykh pidpryiemstvakh [Accounting and analysis of intangible assets in construction enterprises]. Extended abstract of candidate's thesis. Ivano-Frankivsk: Vasyl Stefanyk Precarpathian National University [in Ukrainian].

Zakon Ukrainy «Pro derzhavne rehuliuvannia diialnosti u sferi transferu tekhnolohii»: pryiniatyi 14.092006 roku № 143-V [Law of Ukraine on state regulation of activities in the field of technology transfer from $14^{\text {th }}$ September 2006, No. 143-V]. Retrieved from http://zakon.rada.gov.ua/laws/show/143-16 [in Ukrainian]. 
3.-М. В. Задорожний, д.е.н., професор, Тернопільський національний економічний університет (Україна);

В. В. Ясишена, к.е.н., доцент, Тернопільський національний економічний університет (Україна).

Нематеріальні активи як об'єкт обліку і управління

У статті розглянуто погляди вчених-економістів щодо розуміння сутності поняття нематеріальні активи (HМА) та їх ролі у системі управління підприємством. Основною метою проведеного дослідження є удосконалення понятійного anapamy. Систематизація літературних джерел та підходів до розуміння сутності НМА засвідчила, що існують різні підходи до визначення їх сутності (економічний, юридичний, бухаалтерський, оціночний), які розкриваються у науковій літературі і нормативно-правових документах. Актуальність вирішення цієї наукової проблеми полягає в тому, що через існування розбіжностей у економічному, юридичному, бухаалтерському і оціночному підходах до розуміння сутності НМА відбувається значний розрив між методологією бухгалтерського обліку НМА і сучасними вимогами управління. Складність у трактуванні поняття НМА полягає в тому, що вони включають в себе різні за природою об'єкти. Проаналізовано і виокремлено ознаки, що характеризують НМА. Виявлено переваги та недоліки актуальних підходів до визначення сутності НМА, які розкриваються у науковій літературі і нормативно-правових документах. Запропоновано уточнення тлумачення поняття «нематеріальні активи» де поєднано економічні, юридичні, бухгалтерські, оціночні, управлінські підходи. Нематеріальними активами рекомендовано вважати ідентифіковані і оцінені довгострокові й поточні активи, які не мають фізичного втілення, являють собою права на об'єкти інтелектуальної власності, користування природними ресурсами, майном та організаційними й економічними привілеями, здатні приносити економічну вигоду та мають властивості впливати на формування вартості підприємства, підвищувати його прибутковість $і$ конкурентоспроможність. Запропоновано уточнити редакцію визначення НMA, наведеного в Законі України «Про державне регулювання діяльності у сорері трансферу технологій», що дозволить більш повно розкрити права на об'єкти НМА за групами наведеними в П(С)БО 8, Плані рахунків і у Методичних рекомендаціях з бухгалтерського обліку нематеріальних активів.

Ключові слова: визнання, ідентифікація, інтелектуальна власність, інтелектуальний капітал, невідчутні активи, нематеріальні активи (НMA), немонетарні активи, необоротні активи, облік, оцінка.

Manuscript received: 12.12 .2018

(C) The author(s) 2019. This article is published with open access at Sumy State University. 